\title{
Tasarım Öğrencilerinin COVID-19 Kapanmasındaki Yoğun Uzaktan Eğitim Döneminde Ortaya Çıkan Ergonomik Sorunlarının İncelenmesi
}

\section{A Study on Ergonomic Problems of Design Students During Intense Distant Education Period in COVID-19 Lockdown}

\author{
Mehmet Ali Altın' ${ }^{\text {iD, }}$, Onur Ülker ${ }^{2}$ D \\ ${ }^{1}$ Eskişehir Teknik Üniversitesi, Mimarlık ve Tasarım Fakültesi, İç Mimarlık Bölümü, 26555, Eskişehir, TÜRKIYYE \\ ${ }^{2}$ Eskişehir Teknik Üniversitesi, Mimarlık ve Tasarım Fakültesi, İç Mimarlık Bölümü, 26555, Eskişehir, TÜRKIYE
}

Başvuru/Received: 01/10/2021

Kabul / Accepted: 30/12/2021

Çevrimiçi Basım / Published Online: 31/12/2021

Son Versiyon/Final Version: 31/12/2021

\begin{abstract}
$\ddot{\mathbf{O z}}$
Mimarlık, İç Mimarlık, Endüstriyel Tasarım ve Grafik Tasarım gibi alanlarda eğitim gören tasarım öğrencilerinin günlük ihtiyaçları diğer branşlarda eğitim alan öğrencilere göre farklılık göstermektedir. Tasarım alanında, manuel ve dijital tasarım pratikleri birlikte yürütülür. Öğrenciler elle çizim yaparken bir taraftan da bilgisayar ortamında görselleştirme ya da sunum hazırlamaktadırlar. Bu süreçler yapılan işe uygun vücut pozisyonlarını kullanmayı ve çalışma ortamının uygun şekilde oluşturulmasını da gerektirir. Pek çok öğrenci bulundukları çalışma ortamlarında bu düzenlemeleri sağlarlar. 2020 yılının Nisan ayında Covid-19 salgını nedeniyle geçilen uzaktan eğitim düzeni yüz yüze eğitimdeki pratiklerin pek çoğunun değişmesini gerektirmiştir. Pek çok kurum için hazırlıksız yakalanılan bu durum uzaktan eğitimi yürüten öğretim elemanları kadar öğrencileri de etkilemiştir. Bu çalışmada, COVID-19 salgını esnasında tasarım öğrencilerinin, uzaktan eğitime geçişle birlikte yaşadığı ergonomik değişimler incelenmiştir. Araştırmaya ESTÜ İç mimarlık bölümünde lisans eğitimi alan 147 öğrenci katılım sağlamış ve farklı sınıflarda, farklı cinsiyet, yaş, boy, kilo özelliklerindeki tasarım öğrencilerinin uzaktan eğitim aldıkları yerdeki şartlarının, yeni oluşan sağlık sorunlarıyla ilişkisi ele alınmıştır. Ayrıca uzaktan eğitim sürecinde kullanılan mekan ve mobilyanın, dijital aletlerin sağlık problemlerinin oluşmasındaki rolü incelenmiştir. Tasarım eğitimi açısından örgün eğitim ve uzaktan eğitimin avantajları ve sağlık yönünden ergonomiye bağlı dezavantajları ortaya konulmaya çalışılmıştır.
\end{abstract}

\section{Anahtar Kelimeler}

COVID 19, Uzaktan Ĕ̈itim, Tasarım Öğrencileri, Ergonomi

\footnotetext{
Abstract

The daily needs of design students studying in fields such as Architecture, Interior Architecture, Industrial Design and Graphic Design differ from students studying in other branches. In the field of design, manual and digital design practices are carried out together. While students are drawing by hand, they also prepare visualizations or presentations in the computer environment. These processes also require using body positions suitable for the job and creating a suitable working environment. Many students provide these arrangements in their work environments. The distance education system, which was passed due to the Covid-19 epidemic in April 2020, required many of the practices in face-to-face education to change. In this study, ergonomic changes experienced by design students with the transition to distance education during the COVID-19 epidemic were examined. 147 students who received undergraduate education at ESTU Interior Architecture department participated in the research and the relationship between the conditions of the design students in different classes, different gender, age, height, and weight in the place where they receive distance education and newly emerging health problems was discussed. In addition, the role of space, furniture and digital tools used in the distance education process in the formation of health problems has been examined. In terms of design education, the advantages of formal education and distance education and the disadvantages related to ergonomics in terms of health have been tried to be revealed.
}

Key Words

"COVID 19, Distance education, Design Students, Ergonomics" 


\section{Giriş}

2019 yılının son aylarında Çin'de ortaya çıkan COVID-19 virüsü, kısa sürede tüm dünyayı etkisi altına alan bir salgın haline dönüşmüş̧ür. Günümüzde yürütülen aşılama faaliyetleriyle birlikte kısmen kontrol altına alınmış olsa da virüs üzerinde gelişen farklı mutasyonlar ve aşılamada istenilen seviyeye ulaşılamamış olması nedeniyle salgın etkisini devam ettirmektedir. Dünya Sağlı Örgütü verilerine göre 2021 Kasım ayı itibariyle dünyada COVID-19 salgını sebebiyle hayatını kaybedenlerin sayısı beş milyonun üzerindendir. Yine benzer şekilde salgından etkilenenlerin sayısı da iki yüz kırk sekiz milyon kişiye ulaşmıştır (Who Corona Virus Dash Board, 2021). Virüsün ortaya çıktığı ve öldürücülüğü ve bulaşıcılığı dışında hakkında henüz pek bir bilginin bulunmadığı ilk günlerde ilk önlemler olarak bulaşmayı kolaylaştıran insan temasını azaltmak üzere bireylerin toplu olarak bir araya geldiği ortamlara sınırlamalar getirme yolu benimsenmiş ve devletler bu bağlamda adımlar atmışlardır. Aynı zamanda virüsün dolaşımını engellemek adına seyahat sınırlamaları da getirilmiştir (Türk Tabipleri Birliği Covid-19 Danışma ve İzleme Kurulu, 2020, s. 75). Bu bağlamda ilk ve orta dereceli okullar ile yüksek öğrenim kurumları için uzaktan eğitim sistemi benimsenmiş ve yüz yüze eğitim verilen eğitim kurumu binalarına erişim engellenmiştir (YÖK Basın ve Halkla İlişkiler Müşavirliği, 2020). Uzaktan eğitim altyapısı bulunan eğitim kurumları bu altyapıları işler hale getirerek devam etmiş ve bu konudaki inisiyatif YÖK tarafindan yetki devriyle üniversite yönetimlerine aktarılmıştır. Tüm eğitim sisteminde tek seferde aynı anda bu derece büyük bir değişim ilk defa yaşanmıştır. Bu durum hem eğitimciler hem de öğrenciler için çok farklı sonuçlar doğurmuştur. Eğitimciler yüz yüze eğitime göre planlanmış ders müfredatlarını, uzaktan eğitime göre planlarken öğrenciler uzaktan eğitimde araç olarak kullanılan dijital iletişim teknolojilerine erişme konusunda sıkıntılar da yaşamışlardır. Yüksek öğretimde yaygın olan aile ortamlarından uzakta, farklı şehirlerdeki kurumlarda eğitim alma halindeki öğrenciler için ise durum daha karmaşık bir boyuta ulaşmışırı. Bir dönemi arkada bırakılmış öğretim yılının ikinci döneminde artık eğitim aldıkları şehirlerdeki konaklamaya dair düzenlerini oluşturmuş pek çok öğrenci için eve dönüş yolculukları başlamıştır. Devlet yurtları ve özel yurtların da kapatılmasıyla bu yolculuk pek çokları için kaçınılmaz hale gelmiştir. Eğitim kurumlarının kapanmasını takip eden üç haftalık süre boyunca kurumlar uzaktan eğitim alt yapılarını oluşturmuş ve öğrenciler farklı platformlar üzerinden uzaktan eğitime dahil olmuşlardır. Yüz yüze eğitimde ihtiyaç duyulan eğitim araçları dijital ortamlar ve iletişim teknolojileri ile sınırlandırılmıştır.

Yüksek öğretimin farklı programlarında, farklı öğretim yöntemleri ve bu yöntemlere bağlı farklı araçlar ve ortamlar olsa da yüz yüze eğitimdeki bu paradigma değişiminde en büyük güçlüğün uygulamalı eğitim ağırlıklı programlarda yaşandığı görülmektedir. COVID19 öncesinde de uygulamalı derslerin uzaktan eğitimle işlenmesi üzerine çalışmalar yapılmıştır (Mary V. Mawn, 2011) (Brinson, 2015). Ancak bu çalışmaların pek çoğu kısa süreli, kontrol gruplu deneyler şeklinde yürütülmüş ve eğitimi gündelik hayatın küçük bir kesiti olarak ele almıştır. Bunun yanında teorik ve didaktik dersler için hibrit ya da tümüyle uzaktan eğitim uygulamaları internetin de yardımıyla hayatın bir parçası olarak değerlendirilmeye tabi tutulmuştur. İlk defa 2020 yılında COVID-19 kapanmalarıyla eğitimin yüz yüze yürütülebilmesi için bir alternatif kalmadığında teorik derslerin dışında uygulamalı derslerin de uzaktan eğitimde hayat akışının bir parçası haline gelmesi mümkün olmuş ve bu durum uygulamalı dersler açısından mükemmel bir araştırma zemini oluşturmuştur. COVID-19 döneminde uygulamalı olarak el alınan derslerin işlenmesindeki yeni keşifler ve yöntemler, başarı ve başarısızlık öyküleri gibi pek çok kıstasta değerlendirilmiş çalışma bu dönemde oluşturulmuş ve birçoğu sağlık bilimleri alanındaki bu çalışmalarda ise eğitimin performansının sorgulandığı görülmüştür (McGann, ve diğerleri, 2021). Sağlık bilimleri dışındaki pek çok alan da gerek laboratuvar gerek atölye ortamında pek çok uygulamalı dersi içermektedir.

Fikirlerin çizimlerle anlatıldığı tasarım alanlarında ise uygulamalı dersler eğitimde önemli bir yer tutar. $\mathrm{Bu}$ alanlara mimarlık, endüstriyel tasarım, grafik tasarım ve mühendislikler örnek verilebilir. Fikirlerin görselleştirilmesi için özelleşmiş derslerde iki ve üç boyutlu çizim yeteneği öğrencilere kazandırılmaya çalışılır. Özellikle güzel sanatlar temelli alanlarda çizimle başlayan tasarlama süreci eğitim boyunca zamanla bilgisayarda çizime doğru evrilir. Öğrencilerin masa başında çizim yaptıkları sırada ergonomik olmayan postürlerde uzun saatlerini geçirmeleri çok rastlanılan bir durumdur. Öğrencilerin sınıf içindeki çalışma biçimleri eğitim kurumlarının sağlayabildiği imkanlar doğrultusunda kontrol altındandır. Bu anlamda optimum çalışma donatısı değerlerini saptamak adına çalışmalar yapılmıştır (Arslan ve Çınar, 2015) (Yıldırım ve Kasal, 2005) (Kahya, Ünlüer, Güzeldal ve Demirci, 2018). Ancak öğrencilerin eğitim kurumu dışındaki çalışma alanlarında geçirdikleri vakit de göz önüne alındığında bu anlamda yapılan çalışmaların sayısı oldukça azdır. COVID-19 salgını bu anlamda bir farkındalık oluşturmuştur ve bu kapsamda yapılan çalışmaların sayısında belirgin bir artış meydana gelmiştir. Çalışmaların büyük çoğunluğu eğitim faaliyetlerini uzaktan yürütenlerin ve aynı zamanda salgın kaynaklı kapanma dolayısıyla evden çalışmaya geçen kişilerin yaşadıkları sorunları ve iş ve eğitim performanslarındaki değişimleri araştırmaktadır.

Uzaktan eğitim için örnek vermek gerekirse, Soltaninejad vd. 2020 yılında yapmış oldukları çalışmada, COVID-19 salgın döneminde, uzaktan eğitimin öğrencilere olan etkisini ergonomik faktörlere bağlı kalarak incelemiştir. Çocuklar için eğitim alanlarında ergonominin varlığı öğrenme kalitesini arttırır, stres ve kaygıyı azaltır ve sağlık protokollerinin gözlemlenmesiyle öğrenciler için sağlıklı ve güvenli ortamlar sağlanabilir sonucuna ulaşmışlardır. Araştırma yapılan faktörler, aydınlatma, gürültü, oda sıcaklığı, hava kalitesi ve iç mekân fiziksel şartlarıdır. Araştırmada "Okullar, çocukların yeteneklerini, fiziksel aktivitelerini ve sosyal yönlerini geliştirmek için en uygun ortamdır, uzaktan eğitimde bu önemli faktörler sağlanamadığı için, motivasyon ve ilgide azalma olmaktadır." sonucuna varılmıştır (Soltaninejad, Babaei-Pouya, ve Poursadeqiyan, 2021). 
Choudhary vd. 'nin 2020' de yapmış oldukları çalışmada, COVID-19 salgın döneminde öğrencilerin ve gençlerin iç mekanlara bağlı kalmalarının ve sürekli elektronik cihazları kullanmalarının sonucunda sağlık sorunlarının arttığı ve ergonomi kavramının öne çıktı̆̆ı vurgulanmıştır. Araştırmacılar, 10-18 yaş grubunda 186 katılımcılı anket düzenlemiş, çalışma ortamlarının düzeni, ders dinlerken oturma süreleri, ekran kullanım süreleri, göz ve ekran ilişkisi, bel ve oturma ilişkisi, klavye ve bilgisayar kullanım ilişkisine ait kavramları incelenmişlerdir. İki ay gibi kısa bir sürede, online eğitime katılan öğrencilerin pek çoğunda önemli sorunların geliştiği ve gelecekte kalıcı hasarlara sebebiyet verebileceği ifade edilmiştir. Ayrıca araştırmacılar, ergonomi kavramının ilkokul ve ortaokullarda ders müfredatına eklenmesi gerektiğini belirtmişlerdir (Choudhary, Choudary, Jemal, Kumar, \& Jamal, 2020).

Okuyan ve Bergen yapmış oldukları derlemede, COVID-19 salgın sürecinde uzaktan eğitimin ve uzaktan çalışmanın etkilerinin ve dezavantajlarının, çalışma koşullarını nasıl iyileştirilebileceğine ve sağlık sorunlarının nasıl azaltılacağına dair öneriler getirmişlerdir (Okuyan \& Beğen, 2021). Vellespin ve Prasetyo 2020 yılında, evlerinde uzaktan eğitim gören yirmi dört (24) öğrenciye çevrimiçi yöntem ile anket yapmışlar ve RULA ve REBA kullanarak duruş analizi oluşturmuşlardır. Çalışmaya katılan, öğrencilerin en yüksek puanı RULA'da 7 ve REBA'da 5'tir. Bu seviyedeki risk puanları, vücut duruşu için orta risk grubuna girmektedir. Anket sonuçları incelendiğinde, bel (\%15.37), boyun gibi vücudun yüksek kısımları (\%13.29), üst sirt (\%10.84) ve sağ bilek (\%9.25) tespit edilmiştir. Genel olarak, öğrencilerin ev ortamlarının ergonomik tasarlanmadığı görülmüştür. Mevcut şekilde devam etmesi durumunda, vücut duruşlarının riskli olduğu ve ileride kas iskelet sisteminde rahatsızlıkların oluşacağı düşünülmektedir (Vallespin ve Prasetyo, 2020).

Ayyıldız ve Gümüş 2021 yılında yapmış oldukları çalışmada, Ergonomi dersi alan 100 öğrenciye ABD Çalışma Bakanlığı (OSHA) İş Güvenliği ve Sağlığı dairesinin risk analizi anketini kullanarak, AHP ve TOPSIS metotları ile risk analizi yapmışlardır. Yapılan anket beş farklı alanı kapsamaktadır, bunlar bilgisayar başında çalışma, oturma süreci, bilgisayarların türü ve klavyeler, uzaktan eğitimde kullanılan mekânın fiziksel özellikleri ve psikolojik durum ve memnuniyettir. Bu başlıklardan psikolojik durum ve memnuniyet başlı̆̆ ilk sırayı almıştır (Ayyıldız ve Gümüş, 2021).

Aytar vd. 'nin 2020 yılında yaptıkları çalışmada uzaktan eğitim alan öğrencilere verilen duruş ve ergonomi eğitiminin kas-iskelet sistemi bozuklukları, egzersiz davranışı karar verme dengesi ve fiziksel aktivite düzeylerindeki etkilerini araştırmışlardır. İki grup üzerinde yapılan deneyde ergonomi eğitimi verilen grup ile verilmeyen grup arasında kıyaslama yapılmıştır. Kıyaslama için NMQ-E ve IPAQ-SF anketleri kullanılmıştır. Çalışma sonucunda ergonomi eğitimi alan grup ile almayan grubun ağrı düzeyleri arasında bir fark bulunamamıştır (Aytar, Altıntaş ve Aytar, 2020).

İde ve Gündüz 2021 yılında yaptıkları çalışmada Korona virüs kapanma döneminde üniversite öğrencilerinin yorgunluk düzeyi ve kas iskelet sistemi rahatsızlıkları arasındaki ilişkiyi incelemişlerdir. Araştırmacılar çalışmada Cornell Kas İskelet Sistemi Rahatsızlıkları Anketinin (CMDQ) Türkçeleştirilmiş versiyonu olan T-CMDQ anketini kullanmış ve 154 üniversite öğrencisine bu anketi uygulamışlardır. Vücut bölgelerindeki rahatsızlıkların en çok bel, sırt, boyun ve omuz bölgelerinde olduğunu bulmuşlardır. Kadınların erkeklere göre daha çok zorlanma yaşadığı ortaya çıkmış ve uyku düzeni bozukluklarına dikkat çekilmiştir (İde ve Gündüz, 2021).

COVID-19 salgını tedbirleri kapsamında öğrenciler uzaktan eğitime geçmiştir, aynı zamanda riskin azaltılması için uzaktan çalışma potansiyeli bulunan işler için evden çalışma yolu benimsenmiştir. Bu durum, günümüzde bilgiye ulaşmanın en pratik yolu olan cep telefonu gibi elde taşınabilir cihazların kullanım sıklığını ve süresini artırmışır. Bu bağlamda oluşan ergonomik sorunlara odaklanan çalışmalara literatürde rastlamak mümkündür. Rana ve Mana, 2021 yılında yaptıkları çalışmada bu soruna odaklanmış ve Hindistan'ın farklı şehirlerinden 651 elde taşınabilen cihaz kullanıcısına COVID-19 döneminde yaşadıkları kas-iskelet sistemi rahatsızlıklarını araştıran bir anket uygulamışlardır. Kullanıcılarda kas-iskelet sistemi rahatsızlıklarının vücudun üst bölgesini en çok etkilediği. Cinsiyete bağlı olarak rahatsızlıkların değişkenlik gösterdiği bulgularına ulaşmışlardır(Jain vd., 2021).

Uzaktan eğitim ve uzaktan çalışmanın belli koşullarının aynı olduğu gözlemlenmektedir. Özellikle çalışılan ya da eğitim görülen cihaz başında geçirilen sürenin artışı, kapanma dolayısıyla oluşan hareketsiz yaşam ve ruh halindeki değişimler her iki pozisyon için de benzer durumdadır. Bu sebeple uzaktan çalışma ve ergonomik sorunlar üzerine yapılan literatür taramasına da bu çalışmada yer verilmesi uygun bulunmuştur.

COVID-19 salgını sadece sağlık çalışanları için değil, aynı zamanda evden çalışanlar için de büyük sorunlar getirmiştir. Salgın sürecinde tüm dünyada uzaktan çalışma yaygınlaşmıştır. Bu sebeple de uzaktan çalışmanın, kişiler üzerindeki sağlığa dair etkileri pek çok araştırmaya konu olmuştur. Ergonomik ortamlarda çalışma rutinine sahip çalışanlar için uzaktan çalışma sistemi hem işverenlere hem de çalışanlara bazı avantajlar sunar. Fakat, bazı potansiyel dezavantajları da bulunmaktadır, doğru beslenemeyen ve sosyal ihtiyaçlarını yeterince gerçekleştiremeyen çalışanlar üzerinde olumsuz etkiler oluşturduğu söylenebilir. Uzaktan çalışanlar için başlıca tehlikeler şunlardır: ergonomik iş ekipmanı ve özel bir çalışma alanının bulunmaması, aşırı çalışma riskinin olması ve negatif psikososyal etkilerinin bulunması (Buomprisco vd., 2021). 
ABD'de yapılan bir çalışmada, bilgisayar mühendislerinin ve yazılımcıların COVID-19 salgınındaki evden çalışmaya bağlı memnuniyeti ölçülmüş̧ür. Normalde bilgisayar mühendisleri ofis ortamında tamamlayamadıkları yazılımları evden çalışıp tamamlamaya alışıklardır. COVID-19 salgınından sonra da kalıcı olarak evden çalışma sistemi uygulanması mümkün gözükmektedir. Evden çalışma yönteminin verimliliğini anlamak amacıyla yazarlar (Ford et al., 2020) yazılım mühendislerine iki farklı anket hazırlamışlardır (toplam 3.634 yanıt alınmıştır). Anket sorularının temel noktaları uzaktan çalışmanın faydaları, zorlukları ve fırsatlarıdır. Anketler hem nitel hem de nicel analiz yapılacak şekilde tasarlanmıştır. Bazıları uzaktan çalışma yöntemini aile üyeleri ile birlikte olmanın faydalı olduğu şeklinde değerlendirilirken, bazı çalışanlar için ise çalışma alanlarını aile üyeleri ile paylaşmayı rahatsızlık verici olarak değerlendirmiştir. Anket sonuçlarına göre, üretkenliğin önemli ölçüde artması $\% 11$, aynı seviyede kalması \%32 ve önemli derecede düşmesi \%6 olarak ifade edilmiştir. Evden çalışmanın ilk beş faydası, işe gidiş ve gelişlerdeki zaman kaybının olmaması, maliyetlerin azalması, esnek çalışma saatlerinin olması, aile bireylerine yakın olunması ve normalden daha rahat giysilerin kullanılması olarak ifade edilmiş, uzaktan çalışma sisteminin dezavantajları ise sosyal bağların zayıflaması, sadece iş yaşamı konseptinde sabit bir hayat yaşanması, günlük ergonomi değerlerinde düşüş yaşanması, iş arkadaşları ile zor iletişim kurulması ve fiziksel aktivitelerin azalması ve obezitenin artması olarak değerlendirilmiştir (Ford et al., 2020).

Endenozya'da yapılan bir araştırmada COVID-19 salgını esnasında uzaktan çalışma modeline göre evden çalışan memurların, kas iskelet sisteminde oluşan rahatsızlıklar ve çalışma ortamlarının ergonomik olup olmaması anket yöntemi ile araştırılmıştır. Anket çalışmasına 50 kişi katılmış, anket Google aracılığı ile yapılmışır. Anket sonuçlarına göre çalışanların \%72'si çalışma ortamlarının ergonomisinin iyi olduğunu, \%28'i kas ve iskelet sisteminde bazı ağrıları olduğunu, ağrıların ise stres kaynaklı olduğunu ifade etmişlerdir. Evden çalışma yöntemine göre bilgisayar destekli çalışanların \%100'ünde boyun ağrısı, \%70'inde sırt ağrısı olduğu, \%68'in evde fizik hareketleri yaptığı, \%22'nin ise sadece yattığı, \%42'nin evde çok sıkıldığı, \%24'ün ise evde sinir katsayısının yükseldiği ifade edilmiştir (Widianawati et al., 2020).

Tokyo'da yapılan bir araştırmada, iş yerinde hareketsiz şekilde çalışan işçilerin ve COVID-19 salgını nedeni ile evde hareketsiz kalan çalışanların davranışları anket yöntemi ile araştırılmıştır. Anket internet tabanlı olarak planlanmış ve ankete 1239 kişi katılım sağlamıştır, ankete katılanların yaş ortalaması 44,7'dir ve anket katılımcılarının \%59,3'ü erkektir. Katılımcıların 494 adedi evden çalıştığını ifade etmiştir, evden çalışanların fiziksel aktiveleri, işyerinde çalışan fakat hareketi kısıtlı olan işçilere kıyasla daha azdır. Sonuç olarak evden çalışmanın fiziksel aktivitede bulunmayı azalttığı ve çalışanların daha fazla baskı altında olduğu gözlemlenmiştir (Fukushima et al., 2021)

Kanada'da yapılan bir çalışmada, COVID-19 esnasında evden çalışanların sedanter (hareketsiz) yaşama formunda olup olmadıkları incelenmiş̧ir. Sedanter yaşam şeklinde metabolizma 1.5 kat yavaşlamaktadır. Sedanter yaşam TIP 2 diyabet, kalp ve damar hastalıkları ve kas iskelet sisteminde deformasyona sebebiyet vermektedir. ABD'de çalışanların \%20'si pandemiden önce de evden çalıştı̆̆ını ifade etmiş, pandemi döneminde ise çalışanların \%71'i evden çalıştığını belirtmiştir. Çalışmaya 148 kişi katılmıştır, katılımcıların yaş ortalaması 44,9'dur. Haftalık çalışma saatleri 9:30-17:30 (8 saat) üzerinden değerlendirilmiş. Sonuç olarak 95 kişinin günlük 400-500 dakika arası hiç kalmadan çalıştı̆̆ tespit edilmiştir. Gün içinde hareketli geçen sürenin ise 50 dakikayı geçmediği ifade edilmiştir. Sonuç olarak COVID-19 pandemisi sürecinde çalışanların hareketlerinin azaldığı bu durum bazı sağlık sorunlarına sebebiyet vereceği düşünülmektedir. (Dillon et al., 2021)

Literatürde farklı yaklaşımdaki çalışmalarda da görüldüğü üzere COVID-19 dönemi kapanması ve buna bağlı gelişen uzaktan eğitim ve uzaktan çalışma durumları öğrenciler ve çalışanlar açısından pek çok ergonomik değişimi beraberinde getirmiştir. Bu çalışmada, konu, uzaktan eğitim uygulamaları açısından dezavantajı durumda olduğu düşünülen, uygulamalı eğitimin ağırlıkta olduğu tasarım eğitimi açısından ele alınmaktadır. Bu anlamda, çalışma, tasarım alanının bir parçası olan iç mimarlık bölümü öğrencileri üzerinden örneklenmiştir. İç mimarlık eğitimi dört yıl süren ve 8 dönemden oluşan bir süreçtir. Eğitimin ilk yılında elle çizime dayalı dersler ağırlıklı olarak devam etmekte sonraki yıllarda ağırlık giderek bilgisayar destekli yöntemlere dönüşmektedir. İç mimarlık eğitimi içinde iletişim aracı olarak yoğun olarak iki boyutlu çizimlerden faydalanılır, bunun yanında 3 boyutlu bilgisayar çizimleri ve ölçekli fiziksel maketler de eğitimin parçasıdır. Tasarım bölümlerinin pek çoğunda olduğu gibi öğrenciler ödevlerin çokluğundan yakınırlar. Özellikle haftalık olarak işlenen proje derslerinin düzenli çizim ödevleri uzun zaman ve emek gerektirir. Bu süreçte öğrencilerin sağlıklarını olumsuz etkileyecek uyku, yeme-içme düzensizliği ve ekran ya da masa başında uzun zaman geçirmeye bağlı ergonomik sıkıntılara sıklıkla rastlanır. COVID-19 kapanma döneminde bu sıkıntılara uzaktan eğitimin getirdiği sorunlar da eklenmiştir. Sorunlar girift biçimde ortaya çıktı̆̆ için sorunlara neden olan gündelik rutindeki alışkanlık değişimlerinin kişisel olarak ayrıştırılması çok zordur. Öğrenciler sağlığa ve psikolojik değiş̧imlere bağlı yakınmalarını dile getirseler de her bir sorunun kaynağının nasıl bir alışkanlık değişiminden kaynaklandığını ifade etmekte zorlanmaktadırlar. Bu sebeple, çalışma uzaktan eğitim döneminde farklılaşan dış ve iç etkenlerin neden olduğu sorunları ayrı ayrı ele alarak neden-sonuç ilişkisi analizini benimsemektedir. 


\section{Yöntem}

Araştırma, betimsel istatistiksel analiz ve neden-sonuç ilişkisi incelemesi şeklinde gerçekleştirilmiştir. Uzaktan eğitim alan öğrencilerin sağlık problemlerindeki ve psikolojik durumlarındaki değişimler sonuçlar, öğrencilerin maruz kaldığı ergonomik etkenler ise bu problemleri doğuran nedenler olarak değerlendirilmiştir. Nedenler dört kategoride ve bu kategorilerde kümelenen alt başliklarda ele alınmıştır. Sonuçlar ise iki kategoride ve alt başlıklarıyla değerlendirilmiştir. Kategoriler belirlenirken 8 katılımcılı pilot grupla mülakat yapılmış ve uzman görüşüne başvurulmuştur. Daha önce yapılmış benzer çalışmalarda kullanılan ölçekler incelenmiş ve tasarım öğrencilerinin farklı ihtiyaçları göz önünde bulundurularak araştırma ihtiyaçlarına uygun, var olanlardan farklı bir ölçek geliştirilmiştir. İde ve Gündüz' ün üniversite öğrencileri üzerinde uyguladığ 1 Cornell'in kas-iskelet sistemi rahatsızlıkları anketi mülakatlarda belirtilen görme, işitme, solunum, boşaltım ve sindirim sistemi rahatsızlarını ölçmediği için bu rahatsızlıkların da ankete eklenmesine karar verilmiştir (İde \& Gündüz, 2021). Ölçeği oluşturan ergonomik etkenler: Kişisel özelliklere bağlı etkenler, Çevresel özelliklere bağlı etkenler, Araç-gereç ve donatıya bağlı etkenler ve Eğitimin özelliklerine bağlı etkenler olarak kategorilere ayrılmıştır. Sonuçlar ise: Sağlığa bağlı sonuçlar ve Psikolojik sonuçlar şeklinde kategoriler altında değerlendirilmiştir. Belirtilen kategoriler Şekil 1'de detaylandırılmıştır. Sağlığa bağlı sonuçlar kategorisinde ele alınan alt başlıklar vücudun farklı bölgelerindeki ağrı ve rahatsızlık artışıyla ilişkilendirilmiştir. Ağrı ve rahatsızlık artışının gözlemlenebilmesi için 11 dereceli tek boyutlu ağrı ölçeği kullanılmıştır (Yeşilyurt ve Faydalı, 2020). Etkenler bağımsız, sonuçlar ise bağımlı değişkenler olarak değerlendirilmiş ve sebep- sonuç ilişkisi çözülmeye çalışılmıştır.

Katılımcı görüşleri yapılandırılmış anket sorularıyla değerlendirilmiş, katılımcı görüşlerini sayısallaştırmakta geçerli olan5 dereceli Likert ölçeği kullanılmıştır. Çalışma, Eskişehir Teknik Üniversitesi, Sosyal ve Beşerî Bilimler Bilimsel Araştırma ve Yayın Etiği Kurulu tarafından, 02.07.2021 tarihli 12/1 sayılı kararla etik açıdan uygun bulunmuştur. Anketler, iç mimarlık lisans programına kayıtlı 147 katılımcıya 2020-2021 yarıyılının güz döneminde elektronik ortamda uygulanmıştır. İstatistiksel analizler IBM SPSS V24 'te yapılmıştır.

Neden- sonuç ilişkisini ortaya çıkarmak üzere aşağıdaki araştırma soruları üretilmiştir:

- Kişisel özelliklere bağlı etkenler ve sonuçlar ilişkisi

○ Uzaktan eğitim döneminde öğrencilerin kişisel özellikleri ile oluşan ergonomik sorunlar arasındaki ilişki nasıldır?

- Çevresel özelliklere bağlı etkenler ve sonuçlar ilişkisi

○ Öğrencilerin eğitime katıldıkları ortam ile oluşan ergonomik sorunlar arasındaki ilişki nasıldır?

- Araç-gereç ve donatıya bağlı etkenler ve sonuçlar ilişkisi

$\circ$ Öğrencilerin uzaktan eğitime katıldıkları cihazlarla oluşan ergonomik sorunlar arasındaki ilişki nasıldır?

- Öğrencilerin uzaktan eğitime katıldıkları donatı (mobilya) ile oluşan ergonomik sorunlar arasındaki ilişki nasıldır?

○ Öğrencilerin ödevlerini yaptıkları cihazla oluşan ergonomik sorunlar arasındaki ilişki nasıldır?

- Öğrencilerin ödevlerini yaparken kullandıkları donatı(mobilya) il e oluşan ergonomik sorunlar arsındaki ilişki nasildır?

- Eğitimin ihtiyaçlarına bağlı etkenler ve sonuçlar ilişkisi

○ Öğrencilerin aldıkları ders türü ile oluşan ergonomik sorunları arasındaki ilişki nasıldır?

○ Öğrencilerin aldıkları ders sayısı ile oluşan ergonomik sorunları arasındaki ilişki nasıldır?

○ Öğrencilerin haftalık ders saati sayıları ile oluşan ergonomik sorunlar arasındaki ilişki nasıldır?

○ Öğrencilerin çalışma biçimi ile oluşan ergonomik sorunlar arasındaki ilişki nasıldır?

Araştırma soruları gruplanarak anket soruları haline getirilmiş ve her bir başlık farklı bir ölçek olarak ele alınmıştır. Değişkenler normallik analizi ile kontrol edilmiş ve $n>30$ olduğu için Shapiro-Wilk değeri üzerinden değerlendirilmiştir. Değişkenler arası ilişki analizi için parametrik (t-testi) ve parametrik olmayan (Mann-Whitney U) testler uygulanmıştır. 


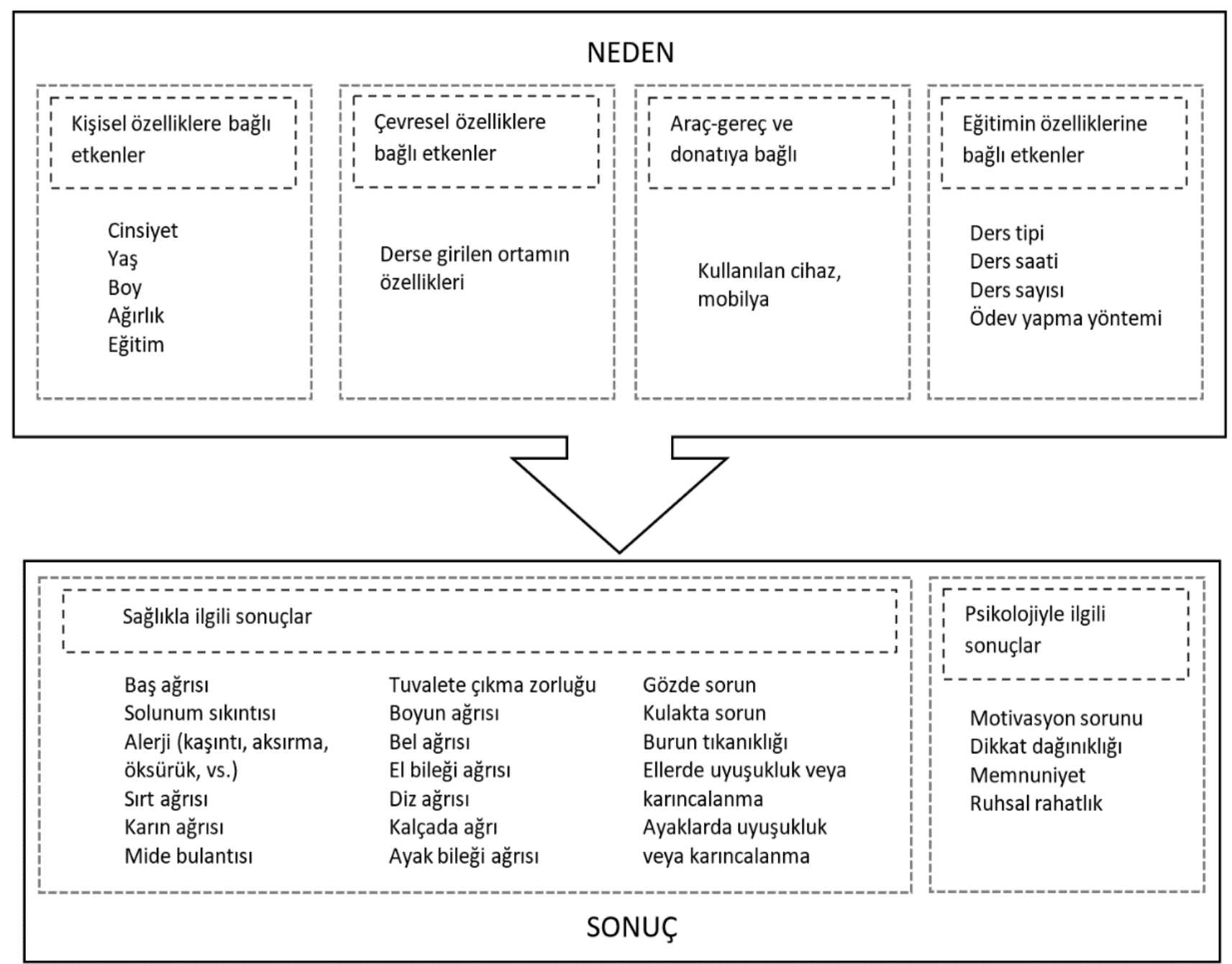

Şekil 1. Neden-sonuç diyagramı

\section{Bulgular ve Yorum}

Araştırmaya katılan 147 öğrencinin 32'si erkek, 115'i kadındır. Katılmıcıların yaş ortalaması 21,27 (std=2,276), boy ortalaması 167,97 cm (std=8,249) ve ağırlık ortalaması 60,830 kg (std=12,8959)'dır. 8 dönemlik eğitimdeki ortalama süre 4,44 (std=2,245) dönemdir. Katılımcıların \%67,3 'ü öğrencilik dışında bir faaliyetle uğraşmadığını \%32,7 'si öğrencilik dışında da bir faaliyetle uğraştığını belirtmiştir. Katılımcıların \%75'i gözlük, \%26,7'si kontakt lens ve \%2,5 'i de uzuvsal protez kullandıklarını belirtmiştir. Rahatsızlık artı̧̧ değerleri Tablo 1'de gösterilmektedir.

Psikolojiye bağlı sonuçlar incelendiğinde, 5 puan üzerinden yapılan Likert puanlamasına göre motivasyon ortalama 3,84, dikkat eksikliği sorunu ise 3,69 puan almıştır. Uzaktan eğitimden memnuniyet 2,62 ve salgın sonrasında da uzaktan eğitimi tercih edeceklerini söyleyenler 2,29 puan ortalamasını vermiştir. 
Tablo 1. Rahatsızlık puanı ortalamaları

\begin{tabular}{lcc}
\hline Rahatsızlık & Ortalama & Std. Sapma \\
\hline Baş ağrısı & 6,20 & 2,791 \\
Solunum sıkıntısı & 2,16 & 2,505 \\
Alerji (kaşıntı, aksırma, öksürük vs. etkilerle) & 2,71 & 3,099 \\
Sırt ağrısı & 7,91 & 2,136 \\
Karın ağrısı & 3,37 & 2,862 \\
Mide bulantısı & 3,21 & 3,010 \\
Tuvalete çıkma zorluğu & 2,34 & 2,861 \\
Boyun ağrısı & 7,71 & 2,279 \\
Bel ağrısı & 7,89 & 2,174 \\
El bileği ağrısı & 6,27 & 3,272 \\
Diz ağrısı & 4,83 & 3,566 \\
Kalçada ağrı & 5,39 & 3,467 \\
Ayak bileği ağrısı & 2,73 & 3,154 \\
Gözde ağrı- batma- yanma- bulanık görme & 7,11 & 2,758 \\
Kulakta ağrı- batma- kaşıntı- çınlama & 3,27 & 3,387 \\
Burun tıkanıklığı & 2,17 & 2,800 \\
Ellerde uyuşukluk ya da karıncalanma & 4,93 & 3,571 \\
Ayaklarda uyuşukluk ya da karıncalanma & 5,18 & 3,355 \\
\hline
\end{tabular}

Kişisel özelliklere bağlı etkenler

Cinsiyete bağlı olarak yapılan değerlendirmede kadınların erkeklere göre daha fazla rahatsızlık artışı yaşadığı görülmüştür. Bu rahatsızlıklar en belirgin şekilde sırt ağrısı, mide bulantısı, boyun, el bileği, kalça ağrısı, gözde ve kulakta sorun, el ve ayaklarda uyuşukluk başlıklarında görülmektedir. Yaşa bağlı olarak yapılan değerlendirmede yaşı fazla olanların dikkat eksikliği ve uyku bozukluğu başlıklarında rahatsızlık artışı gözlemlenmiştir. Boya bağlı olarak yapılan değerlendirmede ise boy artışıla birlikte alerji $(\mathrm{p}=.044)$, el ( $\mathrm{p}=.013)$ ve ayakta ( $\mathrm{p}=.003)$ uyuşma rahatsızlıkları daha az artış sergilemiş̧ir. (Anlamlı ilişki: $\mathrm{p}<.05)$

Çevresel özelliklere bağlı etkenler

Öğrencilerin salgın öncesinde kaldıkları ev ve içinde yaşadıkları odanın durumu da ergonomik özellikleri pek çok açıdan etkilemektedir. Özellikle mekânın hava, aydınlatma ve akustik kalitesi uzun vadede oluşan sağlık sorunlarının da kaynağı olmaktadır. Tüm bunların yanında kişinin derse katıldığı ya da ödevlerini yaptığı mekânın boyutlarından, renginden, mekânın yalnız ya da paylaşımlı olarak kullanımından etkilenen psikolojik sonuçlar da bulunmaktadır. Çevresel özelliklere bağlı etkenler ile sonuçlar arasındaki ilişki bu kavramlar üzerinden değerlendirmeye alınmıştır.

Öğrencilerin uzaktan eğitime geçişten önce yaşadıkları yer incelendiğinde \%47'si kendi evinde, \%27,9'u ailesinin yanında \%10,9'u

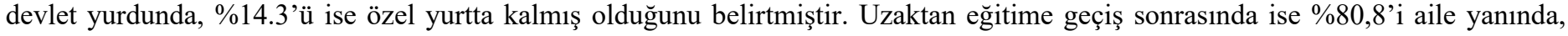
\%19,2'si kendi evinde kaldığını belirtmiştir. Uzaktan eğitime geçiş sonrasında pek çok öğrencinin aile yanına dönmek zorunda kaldığı gözlemlenmektedir. Bunun yanında özellikle ilk sınıftaki öğrenciler okula uzaktan eğitimle başladıkları için yaşadıkları yerden hiç ayrılmamış ve aile yanında kalmaya devam etmişlerdir (ort=\%26,7). Kendi evinde kalmaya devam eden öğrencilerin (ort=15,8) ortalama 6. dönemde oluşu, büyük dönemlerde daha az öğrencinin aile yanına döndüğü şeklinde yorumlanabilir. Uzaktan eğitime 
geçişle birlikte içinde yaşanılan evde beraber kalınan kişi sayısı sorulduğunda ortalama 3,29 (std=1,592), aynı evde beraber uzaktan eğitime katılan kişi sayısı sorulduğunda ortalama 0,82 kişi sonuçları elde edilmiştir.

Öğrencilere yaşadıkları evde uzaktan eğitim derslerine hangi odalarda ne sıklıkta (5 dereceli Likert) katıldıkları sorulmuştur. Tablo 2 (a)'da detaylarıyla gösterildiği üzere en sıklıkla yatak odasından ve salondan katılım sağlanmaktadır. Bunun yanında, aynı soru ödev yaparken oda kullanım sıklığını ölçmek üzere de sorulmuş. Sonuçlar benzer şekilde çıkmıştır. Uzaktan eğitime mutfaktan katılan öğrencilerin vücut ağırlıklarının ( $\mathrm{p}=, 015)$ artı̧ıı dikkat çekicidir.

Tablo 2. (a) Mekânın uzaktan eğitim için kullanım sıklığı (b) Mekânın ödev yapmak için kullanım sıklığı

\begin{tabular}{lrr}
\hline Oda (a) & Ortalama & Std. Sapma \\
\hline Yatak odam & 3,83 & 1,491 \\
Salon & 2,60 & 1,474 \\
Oturma odası & 2,03 & 1,365 \\
Mutfak & 1,60 &, 984 \\
Bir başkasının odası & 1,45 &, 966 \\
Balkon & 1,41 &, 866 \\
Yatak odamdan bağımsız bir & 1,39 & 1,031 \\
çalışma odası & & \\
\hline
\end{tabular}

\begin{tabular}{lrr}
\hline Oda $(\mathbf{b})$ & Ortalama & Std. Sapma \\
\hline Yatak odam & 3,87 & 1,545 \\
Salon & 2,68 & 1,557 \\
Oturma odası & 2,01 & 1,409 \\
Mutfak & 1,66 & 1,101 \\
Balkon & 1,59 & 1,096 \\
Bir başkasının odası & 1,44 &, 929 \\
Yatak odamdan bağımsız bir & 1,41 & 1,065 \\
çalışma odası & & \\
\hline
\end{tabular}

Öğrencilerin uzaktan eğitime katıldıkları ortam ile ergonomik sorunların ilişkisini değerlendirmek üzere mekânsal konforu değerlendiren sorular sorulmuştur. Aydınlatma $(3,87)$, havalandırma $(3,81)$, sıcaklık $(3,71)$, işitsel konfor $(3,41)$ ve oturma konforunu $(2,99) 5$ puan üzerinden değerlendirilmesi istenilen öğrenciler en az puanı oturma konforuna vermişlerdir. Mekânsal konfor yeterliliği artışıyla sonuç ilişkisi incelendiğinde memnuniyetin arttığı, dikkat eksikliği ve motivasyon bozukluğu yakınmalarının azaldığı gözlemlenmiştir. Özellikle işitsel konfor artışı ile motivasyon bozukluğu ve dikkat dağınıklı̆̆ arasındaki ters yönlü ilişki $(p=, 000)$ dikkat çekicidir. Oturma konforunun artışıla rahatsızlıkların hemen hepsinde anlamlı bir azalma görülmekle birlikte sırt ağrısı $(\mathrm{p}=, 002)$, el bileği ağrısı $(\mathrm{p}=, 001)$ ters yönlü ilişkisi dikkat çekicidir. Ayrıca, sıcaklık konforunun artışıyla solunum sıkıntısının azalışı $(\mathrm{p}=, 003)$, havalandırma konforunun artışıyla ise burun tıkanıklı̆̆ sorunun azalışı $(\mathrm{p}=, 004)$ beklenen sonuçları desteklemektedir. İşitsel konforun artışıyla motivasyon bozukluğu ve dikkat dağınıklığı sorunlarının azalışında güçlü bir ilişkinin $(\mathrm{p}=, 000)$ bulunmuş olması da oldukça dikkat çekicidir.

Öğrencilerin uzaktan eğitime girdikleri mekânı psikolojik olarak nasıl yorumladıklarını anlamak üzere olumlu ve olumsuz olarak iki gruba ayrılmış sıfatlarla derecelendirmeleri istenilmiştir. Bun göre 5 üzerinden yapılan puanlamaya göre bulundukları mekânı olumlu sıfatlarla tanımlayanlar ortalama 2,9, olumsuz sıfatlarla tanımlayanlar ise 1,98 ile puanlamışlardır. Sıfat puanlarıyla sonuç iliş̧kisi incelendiğinde olumlu sıfatlarda bedensel rahatsızlıkların azaldı̆̆ı, olumsuz sıfatlarda ise artış gösterdiği kaydedilmiştir. İçinde bulunulan mekânı olumlu sıfatlardan 'güzel' olarak tanımlayanların rahatsızlık artışlarının en az, olumsuz sıfatlardan 'sert' olarak tanımlayanların ise rahatsızlık artışının en çok olduğu gözlemlenmiştir. Olumlu sıfatlarla genel memnuniyet, günlük uyku süresi artarken, olumsuz sıfatlarda motivasyon düşüşü, dikkat dağınıklığı, uyku bozukluğu artışı izlenmiştir. Sıfatlarla uzaktan eğitime katılırken kullanılan odaların ilişkisi incelendiğinde 'yatak odasından bağımsız bir çalışma odası' en çok olumlu sıfatla, 'bir başkasının odası' ise en çok olumsuz sıfatla nitelenmiştir.

Araç-gereç ve donatiya bağll özellikler

İç mimarlık öğrencilerinin eğitimi, eğitim için kullanılan araç gereçle doğrudan ilgilidir. İletişim çizim yoluyla yapıldığı için günümüzde tasarım görselleştirmeleri için bir norm haline gelmiş olan bilgisayar programları öğrencilerin ödev yaparken vaktinin çoğunu bilgisayar başında geçirmesini gerekli kılmaktadır. Uzaktan eğitimle birlikte görselleştirmede el çiziminin kullanımı giderek azalmıştır zira bu türden bir yolu takip etmek çizimin tekrar dijitalleştirilerek bilgisayar ortamına oradan da ilgili ders yürütücüsüne aktarımını gerektirdiği için daha zordur. Eğitimin ihtiyaçları ve uzaktan eğitimin zorunlulukları bir araya geldiğinde öğrencilerin ekran karşısında geçirdikleri süre katlanarak artmıştır. Bu durum eğitimde kullanılan cihazların özelliklerini ve kullanım biçimlerini ergonomik açıdan oluşacak sorunlar anlamında önemli bir hale getirmiştir. Sokağa çıkma yasakları ve ders saatlerinde ekran başında olma zorunluluğunun hareketsizliği arttırdığı bilinmektedir. Hareketsizlikle beraber eğitim için kullanılan cihazla birlikte oturmak ya da çalışmak için kullanılan donatı (oturma elemanı, masa, vs.) da ergonomik açıdan önemli hale gelmektedir. Bu anlamda, bu başlık altında bahsedilen etkenlerle sonuçların ilişkisi ele alınmaktadır. 
Öğrencilerin \%52'1'i masaüstü bilgisayara, \%92,1'i dizüstü bilgisayar, \%17'si tablete, \%87,8'i akıllı telefona ve \%24,5'i akıllı TV'ye erişimlerinin olduğunu belirtmiştir. Öğrencilere Uzaktan eğitime katılırken kullandıkları cihaz sıklıkları sorulduğunda \%92'si dizüstü bilgisayarı, \%26'sı masaüstü bilgisayarı, \%26'sı tableti \%70,8'i akıllı telefonu \%21,8'i ise akıllı TV'yi kullandıklarını belirtmiştir. Öğrencilerin erişimleri olmasına rağmen sabit cihazlara göre mobil cihazları daha çok tercih ettikleri görülmektedir. Cihaz kullanım sıklığı ve sonuçlar ilişkisi incelendiğinde, masaüstü bilgisayar kullanımı arttıkça motivasyon ( $\mathrm{p}=, 013)$ ve dikkat dağınıklığı $(\mathrm{p}=, 035)$ sorunlarında azalma eğilimi görülmektedir. Ayrıca masaüstü kullanımı arttıkça göz sorunlarının azalışı dikkat çekicidir zira masaüstü bilgisayar kullanımında ekran büyüklükleri ve ekran göz mesafesinin mobil cihazlardan farklı olduğu bilinmektedir. Tablet $(\mathrm{p}=, 032)$ ve dizüstü bilgisayar $(\mathrm{p}=, 044)$ kullananların uyku düzeni bozukluğunda artı̧̧ gözlemlenmektedir. Akıllı telefon kullananların bel ağrısı $(\mathrm{p}=, 008)$ ve kalçada ağrı $(\mathrm{p}=, 017)$ gibi kas-iskelet sistemi rahatsızlıklarında artış olduğu gözlemlenmiştir.

En sık kullanılan cihazın kullanılırken vücutla ilişkisi incelendiğinde cihazı elinde tutanlar \%58, diz hizasında \%50, omuz hizasında $\% 40$, göğüs hizasında $\% 64$, bel hizasında $\% 39,9$, göz hizasında tutanlar $\% 68,8$ oranları ortaya çıkmıştır. Cihaz konumu ve sonuç ilişkisi incelendiğinde cihazın elde $(\mathrm{p}=, 003)$, dizde $(\mathrm{p}=, 007)$ ve omuz hizasında $(\mathrm{p}=, 000)$ olması durumları için göz sorunları ilişkisi anlamlıdır.



Şekil 2. Cihaz pozisyonu rahatsızlık ilişkisi

Öğrencilerin uzaktan eğitime girerken en sık kullandıkları cihazları cihaz özellikleri ekran ölçüleri (ort=4,05), ekran çözünürlüğü (ort=4,11), ekran renk kalitesi (ort=4,1), ekran parlaklığ 1 (ort=4,15), kamera (ort=3,58), mikrofon (ort=3,64), hoparlör(ort=3,83), klavye (ort=4,31), wi-fi (ort=3,26), bluetooth (ort $=3,88)$, fare (ort $=4,15)$, ve touchpad (ort $=3,9)$ için yeterlilik açısından değerlendirmeleri istenildiğinde özelliklerin pek çoğu açısından olumlu değerlendirmede bulundukları görülmüştür. Cihaz yeterliliği ile sonuç ilişkisi birlikte değerlendirilmiştir. Ekran ölçülerinin yeterliliği arttıkça motivasyon $(p=, 026)$ ve uyku bozukluğu $(p=, 037)$, sorunlarının azaldığ ve genel memnuniyetin $(p=, 037)$ arttığı gözlemlenmiştir. Wi-fi yeterliliği internet kalitesiyle bağdaştırılmış ve yapılan ön mülakatta da pek çok kez dile getirildiği gibi öğrencilerin derslerdeki kopma, kesilme, yavaşlama gibi sorunlarının kaynağı olarak görülmüş ve wifi yeterlik düzeyinin artışıyla psikolojik sorunların azaldığı dikkat çekici bir şekilde anlamlıdır. Şekil 3 'te cihaz yeterlilik artışıyla azalan

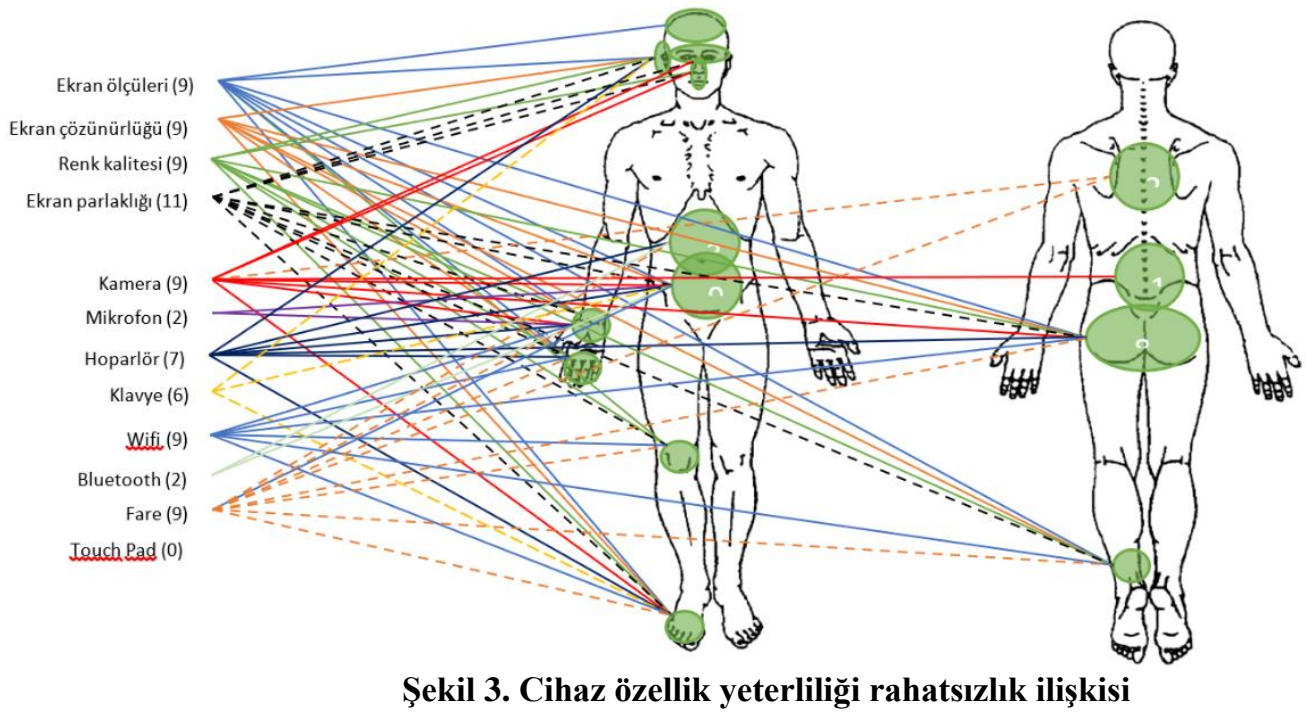


rahatsızlıklar ilişkilendirilmiş olarak verilmiştir. Uzaktan eğitim sırasında ya da bilgisayar karşısında ödev yapıldığı sırada en çok ilişkiye girilen cihaz parçasının ekran olduğu düşünülerek öğrencilerin kullandıkları cihazların ekran ölçüleri sorulmuştur. Kategorik olarak sorulan ekran ölçülerinin ortalama değerinin 13" ile 17" aralığında olduğu ortaya çıkmıştır. Elde edilen değerler ile sonuç ilişkisine bakıldığında ise ekran ölçüsünün artışılla göz sorunları ( $\mathrm{p}=, 007)$, kulak sorunlarının ( $\mathrm{p}=, 000)$ azaldığı gözlemlenmiştir. Ekran ölçüsünün artışı aynı zamanda mide bulantısının $(\mathrm{p}=, 002)$, diz ağrısının $(\mathrm{p}=, 001)$ ve ellerde uyuşukluğun $(\mathrm{p}=, 002)$ azalışını anlamlı biçimde desteklemektedir.

En çok kullanılan cihaz başında geçirilen süre ortalama 6,79 saat $($ std. $=2,104)$ olarak aynı cihaz başından hiç kalkmadan geçirilen süre ise 5,02 saat (std.=1,702) olarak hesaplanmıştır. Hafta içi ekran süresi 5,08 saat (std.=1,269) ve hafta sonu ortalaması 4,71 saat $($ std.=1,558) olarak hesaplanmıştır. Derslerin aralıksız işlenme süresi ile sonuç ilişkisi incelendiğinde süre artışıyla birlikte baş ağrısı $(\mathrm{p}=, 048)$, alerji $(\mathrm{p}=, 035)$, tuvalete çıkma zorluğu $(\mathrm{p}=, 044)$, el bileği ağrısı $(\mathrm{p}=, 001)$, göz sorunu $(\mathrm{p}=, 006)$, ellerde uyuşukluk $(\mathrm{p}=, 002)$, ayaklarda uyuşukluk $(\mathrm{p}=, 005)$ başlıklarında artış olduğu gözlemlenmiştir. Cihaz başında geçirilen süre ile sonuç ilişkisi incelendiğinde süre artışıyla baş ağrısı $(p=, 005)$, diz ağrısı $(p=, 001)$, kalçada ağrı $(p=, 019)$, kulak sorunu $(p=, 003)$, ellerde uyuşma $(p=, 046)$, ayaklarda uyuşma $(\mathrm{p}=, 004)$ başlıklarında artış gözlemlenmiştir. Dersler sırasında öğrencilerin cihaz başında uzun süre ayrılmadan vakit geçirmek zorunda kalması tuvalete çıkma zorluğundaki artışı desteklemektedir.

Tasarım öğrencilerinin derslerde ve ödevlerini yaparken oturmak ya da çalışmak için kullandıkları donatılarda da farklılıklar oluşmuştur. Çevresel etkenler başlığı altında gözlemlendiği üzere öğrencilerin büyük çoğunluğu mekânsal değişiklikler yapmış ve alışık oldukları donatıları geride bırakarak çalışma ortamı olarak kullandıkları yerlerde var olan donatıları kullanmak zorunda kalmışlardır. $\mathrm{Bu}$ durum öğrencilerin uzaktan eğitime katılırken en sıklıkla kullandıkları oturma elemanı sorulduğunda elde edilen puanlardan da belli olmaktadır. Seçenekler arasında yer alan tekerlekli ofis sandalyesi (\%32) en rahat donatılardan birisi olsa da öğrencilerin büyük çoğunluğu metal ya da ahşap mutfak sandalyesini $(\% 42,5)$ en sık kullandıkları oturma elemanı olarak belirtmişlerdir. Öğrencilerin geçici olarak ikamet ettikleri mekanlarda kullanabildikleri donatılarla sınırlandıkları görülmektedir. Ayrıca öğrencilerin derslere katılırken kullanılan donatı sıklı̆ğ sorulduğunda en çok kullanılan donatının çalışma masası olduğu onu da yemek masasının takip ettiği gözlemlenmiştir. Tablo 3 (a)'da detaylarıyla gösterilen donatı kullanım sıklığı dersler dışında kalan zamanlarda ödevlerin yapılmasında kullanılan donatılar için de incelenmiştir.

Tablo 3 (a) Derse katılımda en sık kullanılan donatı (b) Ödev yaparken en sık kullanılan donatı

\begin{tabular}{|c|c|c|c|c|c|}
\hline Donatı (a) & Ortalama & Std. Sapma & Donatı (b) & Ortalama & Std. Sapma \\
\hline Çalışma masası & 4,12 & 1,306 & Çalışma masası & 4,20 & 1,271 \\
\hline Yemek masas 1 & 2,51 & 1,501 & Yemek masası & 2,77 & 1,485 \\
\hline Koltuk & 2,29 & 1,476 & Koltuk & 2,59 & 1,503 \\
\hline Sehpa & 1,90 & 1,262 & Sehpa & 2,08 & 1,306 \\
\hline Yatak & 1,90 & 1,224 & Yatak & 1,99 & 1,301 \\
\hline Çizim masası & 1,62 & 1,167 & Çizim masası & 1,82 & 1,163 \\
\hline Yer (zemin) & 1,59 & 1,052 & Yer (zemin) & 1,71 & 1,294 \\
\hline
\end{tabular}

Çalışma masasından derse katılma sıklığı artışıyla motivasyon düşüklüğü ve dikkat dağınıklığı ters yönde ilişki sergilerken, yemek masasından derse katılanların motivasyon düşüklüğü aynı yönlü ilişki göstermiştir. Derse koltuktan katılanlar diğer tüm donatılara göre çok daha fazla çeşitte rahatsızlık artışı belirtmiştir. Derse katılım ve ödev yapmak için benzer donatıların benzer sıklıkta kullanılmış olması, öğrencilerin çoğunlukla derse katıldıkları yerde ödev de yaptıkları şeklinde yorumlanabilir.

Öğrencilerin uzaktan eğitim derslerine katılırken en sıklıkla hangi oturma pozisyonunu kullandıkları sorulmuştur. Bu soruyu netleştirmek üzere Şekil 3’teki diyagram verilmiştir. Öğrenciler, 5 üzerinden puanladıkları oturuş biçimlerinden a. dik oturuş için 3,29, b. Arkaya dayanmış eğik oturuş için 3,38, c. bacak dik olarak bacak üstünde oturuş için 2,24, d. bacak eğik olarak bacak üzerinde oturuş için 2,83, e. bir bacak kalça altında oturuş için 3,33 ve bağdaş kurmuş oturuş için 2,87 ortalama puanlarını vermişlerdir. Oturuş biçimi sonuç ilişkisi incelendiğinde en avantajlı oturuş biçimimin hem psikolojik hem de sağlik sonuçları açısından dik oturuş olduğu gözlemlenmiştir. Bir bacak eğik biçimde bacak üstünde oturuş ise en sıkıntılı oturuş biçimi olarak ortaya çıkmıştır. Bunların yanında sıklığı yüksek olan oturuş biçimlerinden birisi olan bir bacak kalça altında oturuş mide bulantısı $(\mathrm{p}=, 026)$ ve diz ağrısında $(\mathrm{p}=, 001)$ artışa neden olmuştur. Bağdaş kurmuş oturma biçimi de kalçada ağrı $(\mathrm{p}=, 004)$, ayak bileğinde ağr $(\mathrm{p}=, 009)$ ve ayaklarda uyuşukluk $(\mathrm{p}=, 021)$ sonuçlarında artış göstermiştir. 


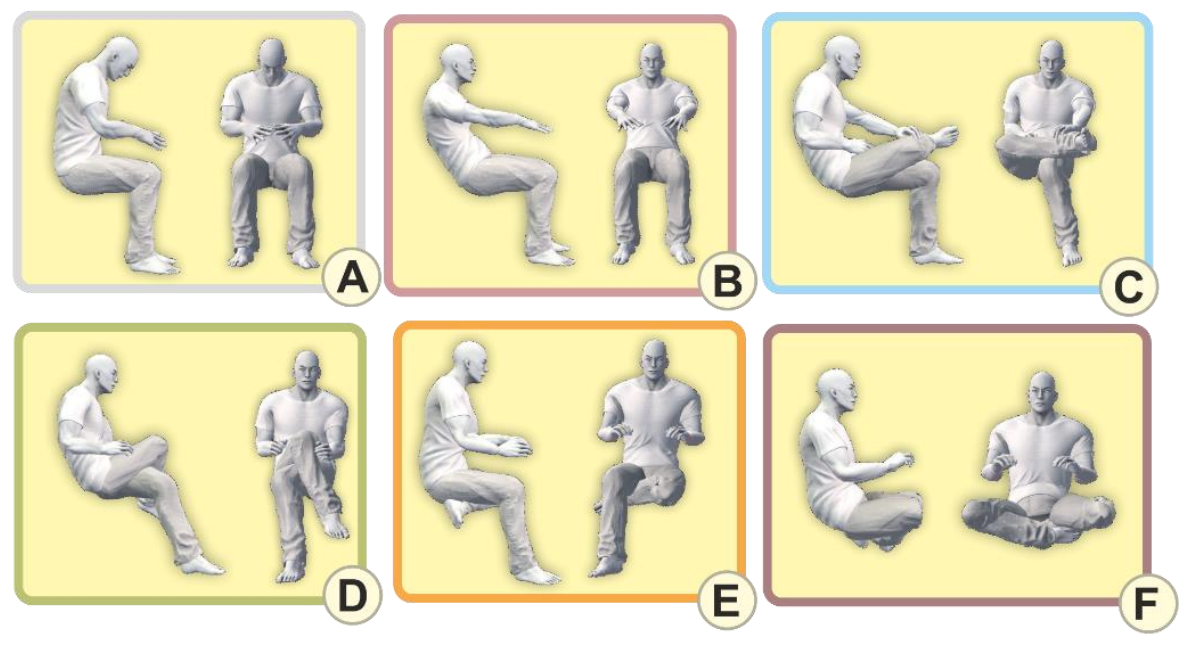

Şekil 2. Oturuş biçimleri diyagramı

\section{Eğitimin özelliklerine bağlı etkenler}

Tasarım eğitiminin diğer eğitim türlerinden farklılıklarının sonuçlar üzerindeki etkisi bu başlık altında incelenmiştir. Tasarım eğitimi daha önce de belirtildiği üzere çizimle iletişimi kullanan bu bağlamda uygulamalı derslerin yoğun olduğu bir eğitim türüdür. Eğitim araçları da bu bağlamda farklılaşmaktadır. Öğrencilerin aldıkları haftalık teorik ders sayısı ortalaması 4,97 (std=1,942), uygulamalı ders sayıs 2,99 (std=1,365)'dur. Alınan haftalık teorik ders saati ortalaması 11,35 saat $(\mathrm{std}=6,279)$ ve uygulamalı ders saati ise 12,57 saat $($ std $=4,461)$ 'tir. Görülebileceği gibi uygulamalı ders sayısı teorik ders sayısından az olsa da haftalık ders saati ortalaması uygulamalı derslerde çok daha fazladır. Uygulamalı dersler, ders yükleriyle orantılı olarak haftalık ders saati açısından daha fazla saate sahiptir.

Ders sayısı ve saatlerinin uygulamalı ve teorik dersler açısından sonuçlarla ilişkisi incelendiğinde uygulamalı ders saati fazla olanların uyku sürelerinin $(\mathrm{p}=, 043)$ daha düşük olduğu, ders sayısı ile yapılan analizde uyku sürelerinin düşüusünün daha da anlamlı bir ilişki sergilediği görülmektedir. Teorik derslerin ise rahatsızlıklarla ilişkisi saptanamamıştır. Bu durum öğrencilerin uygulamalı dersler için uykularından fedakârlık ettikleri şeklinde yorumlanabilir. Uygulamalı ders saatleri arttıkça ekran başında geçen süre $(\mathrm{p}=, 007)$ de artmaktadır. Uygulamalı derslerin sayısı arttıkça aralıksız ders işleme süresi $(\mathrm{p}=, 004)$ ise azalmaktadır. Tasarım öğrencilerinin dersler dışındaki zamanlarının çoğunluğunun ödev yapmakla geçtiği bilinmektedir. Bu sebeple ödev yaparken kullandıkları yöntemler incelenmiştir. Öğrencilere en sıklıkla hangi ödev hazırlama yöntemini kullandıkları sorulmuştur. Öğrencilerin sıklığ 5 üzerinden değerlendirdikleri cevaplarında öğrencilerin en sıklıkla internette araştırma yaptıkları ve bilgisayarda sunum hazırlamanın ikinci sırada geldiği görülmektedir. Tablo 4'te ayrıntılarıyla gösterildiği üzere elde çizim ve kesme yapıştırma gibi manuel aktivitelerin bilgisayar başında yapılanlara göre çok daha az olduğu anlaşılmaktadır. Bu tür aktivitelerin büyük dönemdeki öğrencilerden daha çok küçük dönemdeki öğrenciler tarafından tercih edildiği gözlemlenmektedir. Özellikle bilgisayarda sunum hazırlamanın ikinci sırada en yüksek sıklıkla kullanılması uzaktan eğitim döneminin etkisini göstermektedir. Ödev yapma yöntemi sonuç ilişkisi incelendiğinde elde çizim yöntemini sıklığı arttıkça bel ağrısı $(p=, 014)$ ve ayak bileği ağrısında $(p=, 002)$ artış olduğu gözlemlenmiştir. Bunun yanında bilgisayarda çizimin sıklığı arttığında baş ağrısı $(\mathrm{p}=, 008)$, kalçada ağrı $(\mathrm{p}=, 034)$, ayak bileği ağrısı $(, 014)$, göz sorunları $(\mathrm{p}=, 028)$, kulak sorunları $(\mathrm{p}=, 002)$, ellerde uyuşukluk $(\mathrm{p}=, 028)$, ayaklarda uyuşukluk $(\mathrm{p}=, 014)$ rahatsılılıklarında artış gözlemlenmiş̧ir. Sesli-görüntülü sohbet sıklı̆̆ının artışı ile tuvalete çıkma zorluğu $(\mathrm{p}=, 010)$, el bileği ağrısı $(\mathrm{p}=, 046)$, diz ağrısı $(\mathrm{p}=, 039)$, ellerde uyuşukluk $(\mathrm{p}=, 015)$, ayaklarda uyuşukluk $(\mathrm{p}=, 007)$ rahatsızlıklarında artış görülmüştür. Bilgisayarlı çalışma yöntemlerini sıklıkla kullananlarının rahatsızlık artış çeşitlerinin manuel yöntemlere göre daha fazla oluşu dikkat çekicidir. Bilgisayarlı yöntemleri sıklıkla kullananlarda özellikle tuvalet çıkma rahatsızlı̆̆ında belirgin bir benzerlik bulunmaktadır.

Tablo 4 Ödev yaparken kullanılan yöntem

\begin{tabular}{lrrrrr}
\hline Yöntem & Ortalama & Std. Sapma & Yöntem & Ortalama & Std. Sapma \\
\hline İnternette araştırma & 4,39 &, 831 & Bilgisayarda çizim & 3,67 & 1,279 \\
Bilgisayarda sunum hazırlama & 3,96 & 1,164 & Sesli görüntülü sohbet & 3,58 & 1,334 \\
Elde çizim & 3,81 & 1,149 & Okuma & 3,48 & 1,201 \\
Bilgisayarda yazı (word vs.) & 3,69 & 1,146 & Kesme- Yapıştırma (maket vs.) & 2,53 \\
\hline
\end{tabular}


Yukarıda tasarım eğitiminde uzaktan eğitimin yarattığı sağlığa ve psikolojiye bağlı sorunlar iç mimarlık öğrencileri üzerinden örneklenerek analiz edilmeye çalışılmıştır. Uzaktan eğitimde dizüstü bilgisayarların kullanımındaki baskınlık diğer çalışmaları destekler niteliktedir (İde ve Gündüz, 2021). Rahatsızlığa dair bulgular daha önce yapılan çalışmaları destekler niteliktedir ve boyun, sırt ve bel bölgesinin en çok rahatsızlık bildirilen bölgeler olduğu görülmektedir (Vallespin ve Prasetyo, 2020) (Choudhary, Choudary, Jemal, Kumar ve Jamal, 2020). Bu durumun bilgisayar kullanımındaki artışa bağlı olduğu düşünülmektedir. Yakınmaların masaüstü bilgisayarlardansa dizüstü bilgisayar kullanımında artışı da dizüstü bilgisayarların kompakt yapıda üretilmesi nedeniyle ekran klavye ve fare dağılımının masaüstü bilgisayarlara göre daha az ergonomik oluşuyla bağdaştırılabilir. Bedensel rahatsızlıklar üzerinden yürütülen çalışmaların çoğunluğu kas-iskelet sistemi rahatsızlıklarına odaklanmıştır, bu çalışmada rahatsızlıklar ağrı ile ilişkilendirilerek vücudun görme, işitme, sindirim ve boşaltım sistemi rahatsızlıklarını da kapsayacak şekilde genişletilmesi sağlanmıştır. Bu bağlamda özellikle görme ve işitmede uzaktan eğitim döneminde artan rahatsızlıklar dikkat çekicidir. Genel ortalamada rahatsızlık artışı anlamında yüksek bir rakamda olmayan tuvalete çıkma sorunu ise ilişki analizlerinde ilginç sonuçların ortaya çıkmasına neden olmuştur. Uzayan ders süreleri ya da uzun süre oturur vaziyette olmayla tuvalete çıkma zorlukları arasında mantıklı ilişkiler ortaya çıkmıştır. Motivasyon düşüklüğü ve dikkat dağınıklığı gibi psikolojik sonuçları etkileyen faktörlerin çoğunlukla görme ve işitme gibi duyusal rahatsızlıklarla ilişki kurmaktadır.

\section{Sonuç}

Yapmış olduğumuz çalışmada, toplam 147 adet gönüllü öğrenciye internet ortamında anket uygulanmış, uzaktan eğitim sürecinde ev içindeki çalışma alanları ve kas-iskelet sistemi rahatsızlıkları incelenmiştir.

Neden-sonuç ilişkisiyle değerlendirildiğinde kişisel, çevresel, araç gereç ve donatıya bağlı etkenler girift biçimde ve uzun vadede gündelik hayatı etkilerken, karın ağrısının akşam fazla kaçırılan yemeğe bağlanması, bel ağrısının üşütmeyle, boyun ağrısının yanlış yapılmış bir hareketle yani hatırlatılan en yeni olaylarla ilişkilendirilmesi çok doğaldır. Uzaktan eğitim döneminin ve öğrencilerin bu dönemde yaşadıklarının ne çok kısa ne de çok uzun olması, etkenlerin sonuçlarla ilişkisinin gözlemlenebilmesi için elverişli bir örnek oluşturmuştur. Araştırma bulgularının çoğu, sonuçlar olarak ele alınan psikolojik ve sağlığa bağlı sorunların ergonomik yanlışların kısa olmayan bir vadede vücut üzerindeki etkisini göstermesi bakımından kıymetlidir.

Uzaktan eğitim sürecinde katılımcıların kas ve iskelet rahatsızlıkları incelendiğinde, katılımcıların uzaktan eğitim döneminde daha önceye göre artış gösteren rahatsızlıklarını puanlamaları (0-10 aralığında) istenildiğinde bel ağrısı (ort=7,89), boyun ağrısı (ort=7,71), sırt ağrısı (ort=7,91) ve göz sorunları (ort=7,11) diğer rahatsızlıklara göre daha çok artış göstermiştir. Katılımcıların \%43'ü uzaktan eğitim döneminde vücut ağırlıklarının arttığını, \%33,3'ü azaldığını ve \%23,7'si değişmediğini belirtmiştir. Katılımcıların günlük uyku sürelerinin ortalamaları 6,14 saattir. Katılımcıların \%81,2'si uzaktan eğitim döneminde uyku düzenlerinin bozulduğunu belirtmiştir. Katılımcıların, ağırlığa bağlı olarak yapılan değerlendirmede, kilosu daha fazla olanların solunum sıkıntısı, sırt, karın, bel, diz ve kalça ağrısı, mide bulantısı el ve ayaklarda uyuşmalarında daha fazla artış olduğu tespit edilmiştir.

Ara vermeden devam edilen bir ders motivasyon eksikliği ve dikkat dağınıklığı yapabildiği kadar uzun vadede tuvalete çıkma sorunları da oluşturmaktadır. Uzun saatler boyunca çok parlak bir ekrana bakmanın uyku bozukluklarıyla ilişkisi uykuya dalamayan öğrencinin geç saatte içtiği kahveyi belki de boşuna suçladığının da göstergesi olacaktır.

Uzaktan eğitim döneminde yapılan bu çalı̧̧ma belki tekrar yakalanması çok zor olan çok özel şartları kullanarak ergonominin rahatsızlıklarla olan ilişkisini ortaya koymaya çalışmıştır. Buradan hareketle ergonomik sorunların anlık değişimlerle çözülemeyeceği, yaşam kalitesinin muhafaza edilmesi için uzun vadeli planlar yapılması gerektiği üzerinde durulmalıdır.

Gelecek çalışmalarda, öğrencilerin OWAS, BAUA, RULA ve REBA yöntemleri kullanılarak uzaktan eğitim sürecinde tasarım öğrencilerinin ev içindeki hareketleri incelenip, kas iskelet sistemindeki zorlanmaların tespit edilmesi ve elde edilen sorunların çözümlerinin tartışılması hedeflenmektedir.

\section{Referanslar}

Arslan, A., \& Çınar, H. (2015). Ergonomik Açıdan Proje Tasarım Atölyelerinin İncelenmesi. Süleyman Demirel Üniversitesi, 3(3), 347-354.

Aytar, A., Altıntaş, A., \& Aytar, A. (2020). Effects of posture and ergonomics training for studentsreceiving distance education during the covid-19pandemic on musculoskeletal pain, exercise behaviordecision-making balance, and physical activity level. Journal of Exercise Therapy And Rehabilitiation, 7(2), 137-144. 
Ayyıldız, E., \& Gümüş, A. (2021). A novel distance learning ergonomics checklist and risk evaluation methodology: A case of Covid-19 pandemic. Human Factors and Ergonomics in Manufacturing \& Service Industries, 31(4), 397-411.

Brinson, J. (2015, Eylül). Learning outcome achievement in non-traditional (virtual and remote) versus traditional (hands-on) laboratories: A review of the empirical research. Computers \& Education, 218-237.

Buomprisco, G., Ricci, S., Perri, R., \& de Sio, S. (2021). Health and Telework: New Challenges after COVID-19 Pandemic. European Journal of Environment and Public Health, 5(2), em0073. https://doi.org/10.21601/ejeph/9705

Choudhary, M., Choudary, A., Jemal, S., Kumar, R., \& Jamal, S. (2020). The Impact of Ergonomics on Children Studying Online During COVID-19 Lockdown. Journal of Advances in Sports and Physical Education, 3(8), 117-120.

Dillon, K., Hiemstra, M., Mitchell, M., Bartmann, N., Rollo, S., Gardiner, P. A., \& Prapavessis, H. (2021). Validity of the occupational sitting and physical activity questionnaire (OSPAQ) for home-based office workers during the COVID-19 global pandemic: A secondary analysis. Applied Ergonomics, 97, 103551. https://doi.org/10.1016/j.apergo.2021.103551

Ford, D., Storey, M.-A., Zimmermann, T., Bird, C., Jaffe, S., Maddila, C., Butler, J. L., Houck, B., \& Nagappan, N. (2020). A Tale of Two Cities: Software Developers Working from Home During the COVID-19 Pandemic.

Fukushima, N., Machida, M., Kikuchi, H., Amagasa, S., Hayashi, T., Odagiri, Y., Takamiya, T., \& Inoue, S. (2021). Associations of working from home with occupational physical activity and sedentary behavior under the COVID-19 pandemic. Journal of Occupational Health, 63(1). https://doi.org/10.1002/1348-9585.12212

İde, D., \& Gündüz, T. (2021). Korona Virüs Kapanma (Kısıtlama) Döneminde Üniversite Öğrencilerinin Yorgunluk Düzeyi Ve Kasİskelet Sistemi ları Arasındaki İlişkinin Bazı Değişkenler Açısından İncelenmesi. Ergonomi, 4(2), 107-118.

Jain, R., Rana, K. B., \& Meena, M. L. (2021). Association of individual and device usage factors with musculoskeletal disorders amongst handheld devices users during homestay due to pandemic. International Journal of Workplace Health Management. https://doi.org/10.1108/IJWHM-06-2020-0104

Kahya, E., Ünlüer, G., Güzeldal, Z., \& Demirci, Z. (2018). Bir Yüksek Öğretim Kurumunda Öğrenci Siralarının Uygunluğunun Analizi. Ergonomi, 1(2), 59-76.

Mary V. Mawn, P. C. (2011). Hands-on and online: scientific explorations through distance learning, Open Learning. The Journal of Open, Distance and e-Learning, 26(2), 135-146. doi:10.1080/02680513.2011.567464

McGann, K., Melnyk, R., Saba, P., Joseph, J., Glocker, R., \& Ghazi, A. (2021). Implementation of an E-Learning Academic Elective for Hands-On Basic Surgical Skills to Supplement Medical School Surgical Education. Journal of Surgical Education, 78(4), 1164-1174.

Okuyan, C., \& Beğen, M. (2021). Working from home during the COVID-19 pandemic, its effects on health, and recommendations: The pandemic and beyond. Perspectives in Psychiatric Care, 1-7.

Soltaninejad, M., Babaei-Pouya, A., \& Poursadeqiyan, M. (2021). Ergonomics factors influencing schooleducation during the COVID-19 pandemic :A literature review. Work, 68(1), 69-75.

Türk Tabipleri Birliği Covid-19 Danışma ve İzleme Kurulu. (2020). COVID-19 Pandemisi İki Aylık Değerlendirme Raporu. Türk Tabipleri Birliği. 11 7, 2021 tarihinde https://www.ttb.org.tr/kollar/COVID19/yayin_goster.php?Guid=00ce3418-96a311ea-baf3-777c09b98775 adresinden alınd1

Vallespin, B., \& Prasetyo, Y. (2020). Posture Analysis of Students doing Online Class at Home during COVID-19 Pandemic. 2020 IEEE 7th International Conference on Engineering And Applied Sciences (ICETAS), (s. 1-6). Kuala Lumpur.

Who Corona Virus Dash Board. (2021, 10 7). covid19.who.int: http://covid19.who.int adresinden alınd1

Widianawati, E., Khorioni, A., Nugroho, B. Y. S., \& Wulan, W. R. (2020). The ergonomics design of Work-From-Home Facility during COVID-19 Outbreak inIndonesia and Its Implications for Musculoskeletal. Pakistan Journal of Medical and Health Sciences, 14(4), 1619-1622.

Yeşilyurt, M., \& Faydalı, S. (2020). Ağrı değerlendirmesinde tek boyutlu ölçeklerin kullanımı. Anadolu Hemşirelik ve Sağllk Bilimleri Dergisi, 23(3), 444-451. 
Yıldırım, K., \& Kasal, Ö. (2005). Çizim Mekanlarında İnsan - Eylem - Donatı Elemanı. Politeknik Dergisi, 8(3), 289-299.

YÖK Basın ve Halkla İlişkiler Müşavirliği. (2020, 3 13). Yök Açıklamalar: https://basin.yok.gov.tr/AciklamaBelgeleri/2020/02coronavirus-bilgilendirme-notu-1.pdf adresinden alındı 